\title{
Effect of Trade Diversification on Economic Growth of ECOWAS Countries
}

\author{
Ogunyemi Joseph Kayode \\ Department of Banking and Finance \\ Faculty of Management and Social Sciences \\ Adekunle Ajasin University, P.M.B 001 \\ Akungba Akoko, Ondo State, Nigeria \\ Dare Funso David \\ Ph.D, Department of Banking and Finance \\ Faculty of Management and Social Sciences \\ Adekunle Ajasin University, P.M.B 001 \\ Akungba Akoko, Ondo State, Nigeria \\ Adewole Joseph Adeyinka \\ Department of Banking and Finance \\ Faculty of Management and Social Sciences \\ Adekunle Ajasin University, P.M.B 001 \\ Akungba Akoko, Ondo State, Nigeria \\ E-mail: princeadeyinkaadewolej@gmail.com
}

\begin{abstract}
This study investigated the effect of trade diversification on economic growth of ECOWAS countries. The study has looked at the determinants of exports and imports in some selected ECOWAS countries. The selected ECOWAS countries are Benin, Ghana, and Nigeria. The employed a model form of the GMM estimator was adopted but the empirical validation shall be based on ordinary panel regression. The study revealed that the activities of the main sector when rated as a percentage of the gross domestic product is a significant factor that influences the exports and imports in these selected countries. This means that the activities done in the main sector of these economies have significant effect on the value of exports and imports. The activity of the main sector is huge and voluminous enough to accommodate some level of significant imports in order to assist production which will also be exported. The study has also revealed that the service sector is also a significant factor that influences the exports and imports of these selected ECOWAS countries. Many experts are imported into the service sector of these countries and thus these served as a significant factor that possess influence on the performance of exports and imports in the countries. There is a negative and weak correlation between primary exports and service as a percentage of GDP. Invariably, it can be said that the level of primary exports may not be related with the service sector, thus, the association is expected. The main sector performance is found to be positively correlated with the primary exports in the selected ECOWAS countries. The author then suggested that there is urgent need for ECOWAS states to place more emphasis on the exports of manufacturers' products and make efforts to reduce concentration on exports of primary (agriculture and fuel) products. This will help improve their international trade performance especially with respect to reducing term of trade losses and unfavorable shocks in foreign earnings. Also, the region should focus on production of products for domestic need; in doing this, the ECOWAS states will escape the trap of homogenous export and foster more intra-trade links. The region should see production as major objective rather than exports; this enhances industrial activities and innovations in the region. This attempt retains economic gains of resource within the region and foster economic well-being, the critical mass of ECOWAS challenge is weak productive capacity, this has accentuated the progress of the member states and the sole cause of social and economic evils within the region. ECOWAS should see exports as originating from domestic sufficiency.
\end{abstract}

Keywords: Trade Diversification, Economic Growth, ECOWAS Countries.

\section{Introduction}

Many economies of the world are basically interested in measures that can guarantee them viable and robust economic statues. This quest is more pronounced among the less developed countries (LDCs) than the developed countries (DCs) of the world. To achieve this noble objective, developing economic are constantly implementing 
policies that would not just increase their output but also, placed them in a very competitive position in the global economy.

Among the English speaking countries in the ECOWAS sub-region in Africa, one of the policies embark upon is the management of their exchange rate level to encourage productivity. This step is in line with the understanding that exchange rate volatility (ERV) remain a source of concern as currency values partially determine the price paid or received for output and, consequently, this affects the profits and welfare of producers and consumers (Choudhri \& Schembri, 2014). This implies that, ERV can influence the volume of output a country can produce since the cost of production is been determined by the cost of production.

The exchange rate is the domestic price of foreign money. It can be simply viewed as the price of one currency in terms of another. In the wake of the recent global financial crisis in 2008/2009, there have been major fluctuations in the exchange rates of many countries, resulting in widespread exchange rate misalignments and re-alignments among countries. Since the seventies, there has been an increasing importance attached to exchange rate in many countries, which could be attributed to the following among other reasons: the floating exchange rate variability and volatility as well as the need for foreign exchange risk exposure management; the globalization process and the resultant increased rate and volume of fund flows among nations; the trade liberalization undertaken by developing countries since 1980s, resulting in opening up their economies; the internationalization of modern business; the continuing growth in world trade relative to national economies; the trends towards economic integration in some regions; and the rapid pace of change in the technology of money transfer.

Tarawalie, Sissoho, Conte, and Ahortor (2012) investigate the effects of exchange rate volatility on output growth and inflation in the West African Monetary Zone (consisting of Ghana, The Gambia, Guinea, Liberia, Nigeria and Sierra Leone) following exchange rate regime shift. Results from their study reveal that while exchange rate volatility is inflationary across all the countries, its effect on output growth differ. Specifically, volatility and depreciation in particular negatively affects real GDP growth in Liberia and Sierra Leone but positively impacts on output in the other countries albeit weakly. The difference in direction and magnitude of effect is not far-fetched from the differences in macroeconomic conditions prevailing in each country.

However, Razaxadehkarsalari, Haghiri and Behrooznia (2011) stress that depreciation of exchange rate through external forces from the aspect of government tends to cause a shift from foreign goods to domestic goods. Thereby, leads to diversion of income from importing countries to countries exporting through a shift in terms of trade, and this tends to have impact on the exporting and importing countries' economic growth. Razazadehkarsalari, Haghir, and Behrooznia (2011) argue further that exchange rate depreciation has a negative effect on developing countries.

However, the debate on exchange rate volatility and uncertainty has long divided economists as a result of different perspectives and methodologies of enquiry. Some studies supported the fixed exchange rate while others argued for the floating system. Idika (1998) argues that frequent changes in foreign exchange policies in Nigeria were caused by unstable political environment and have prevented these policies from coming full circle within the economy. Exchange rate stability which is essential ingredient for growth is influenced greatly by the appropriate policy mix by governments in their quest to attain macroeconomic objectives. Nigeria being an economy that depends majorly on revenue from oil would surely feel the impact of exchange rate volatility. Study carried out by World Bank (2003), shows that many oil producing nations are exposed to variations in exchange rate due to their large oil wealth. However, this variation in exchange rate will then act as tax on investment in traded goods production especially agriculture and manufacturing which have an adverse impact on trade performance. Moreover, high volatility in exchange rate is harmful to economic growth, and this problem is majorly associated with less developed countries (LDCs) like Economic Countries of West Africa State (ECOWAS) countries because of the extreme volatility of their income streams and mono-economy.

The exchange rate directly influences prices and /or profitability of traded and non-traded goods. It is a relative price and as such affects the allocation of resources over the short to medium term. The impact of sustained movements of the exchange rate on the competitive position of domestic industry vis-à-vis foreign industry in both domestic and foreign markets is the key transmission mechanism. In effect, uncertainties resulting from unanticipated changes in the domestic and international macroeconomic environments are also key factors. This is more striking in the developing countries which depend heavily on external trade: export to earn foreign exchange, imports to purchase consumer, intermediate and capital goods as well as external borrowing to finance the foreign exchange gap. Therefore, the dependent peripheral structure of these economies is a major factor in the determination of exchange rates. 
Since the introduction of fixed exchange rate regime and adoption of a generalized floating system by the industrialized countries in 1973, most developing countries including ECOWAS, have adopted various types of exchange rate policies ranging from the peg system, weighted currency basket, managed floating and more recently to the monetary zone arrangement (Mordi 2006). The inconsistence in management of various exchange rate policy adopted so far in Nigeria to check the high rate of volatility in exchange rates has jeopardized the overall macroeconomic objectives of the government, especially trade performance, since maintaining a relatively stable exchange rate within a country enhances and boosts economic growth (Mordi,2006; Mahmood \& Ali, 2011; \& Aliyu 2011).

Scholars and researchers have put forward suggestions that exchange rate volatility may effects outputs negatively or positively. Bundesbank (2010) opined that market agents more than ERV determine the level of output. This position is been supported by the view of previous scholars like Cushman (1983) and Lastrapes (1992) who maintained that if economic agents are moderately risk averse the impacts of exchange rate volatility on outputs will be negative. Additionally, some scholar believed that the negative impact may come directly through uncertainty and adjustment costs, and indirectly through its effect on allocation of resources and government policies (Aliyu, Yakub, Sanni, \& Duke, 2013). Also, some scholars reported the possibility of both positive and negative relationships, and some still submitted a no relationship between these variables (Bergvall, 2004; Lama \& Medina, 2010). However, numerous studies still submitted the existence of positive relationship between ERV and output (Aron., Elbadawi, \& Khan, 1997; Bahmani-Oskooee, 1991; Gbesola \& Garba, 2014).

The overall evidence is best characterized as mixed as the results are sensitive to the choices of proxies for exchange rate volatility, sample period, model specification, and countries considered. Nevertheless, the relationship is still vital enough to be explored especially for the principal ECOWAS countries namely, Nigeria, Ghana, Gambia, Sierra Leones, and Liberia, due to various macroeconomic events, for instance the global financial crisis in 2007/2008. Due to these events the relationship between their major trading partners is of interest. More so, for most of these countries production activity have been one of the major engines of economic growth. Based on the inconclusiveness of previous study in terms of theoretical and empirical findings, this study tries to take a different approach in analyzing the relationship. Previous work used autoregressive conditional heteroscedastic (ARCH) and generalized autoregressive conditional heteroscedastic (GARCH 1,1) to investigate the long run and the short run relationship between exchange rate volatility and output level. The existence of inconclusiveness in the explanation of the relationship between exchange volatility and output have led policy makers and researchers to investigate the nature and extent of the impact of such movements on volume outputs. However, this study investigate this relationship performing Granger causality test in the vector error correction (VECM) framework as in the study of Baak (2008). Furthermore, this study looked at the relationship from an aggregate point of view (ECOWAS) not at country level. Thus in the light of trade performance, the purpose of this study is to investigate the determinant of trade performance in Economic Countries of West Africa State.

The main objective of this study is to examine the effect of trade diversification on economic growth of ECOWAS countries from 1980 to 2017. To achieve this, the specific objectives are also to identify determinants of exports and imports in selected ECOWAS countries, to determine the impacts of export determinants on export performance in selected ECOWAS countries, to analyse the effects of import determinants on import performance in the selected ECOWAS countries.

The hypotheses to be tested in this study are stated in a null form which are (1) Exports and imports have no significant impact on trade performance in ECOWAS countries (2) There is no significant impacts of import determinants and import performance in Selected ECOWAS countries (3) There is no significant effect of import determinants on import performance in ECOWAS countries.

\section{Theoretical Framework}

This presents a straight-ward generalization of the model proposed by Herzer and Nowak-Lehnmann's (2006) as used by Gustavo Ferreira (2009) to test the hypothesis that export diversification has influenced economic growth in Costa Rica via externalities of learning-by-exporting and learning-by-doing.

According to Gustavo Ferreira (2009), the economy is constituted by n sectors from which s are export sectors, thus $\mathrm{S} € \mathrm{n}$. It also assumed that each i sector is represented by one firm, and that their corresponding output, at a given point in time $\mathrm{t}$, is determined by a neoclassical production function:

Yit = fit (Kit, Lit, Pt) ------------ (1) 
Where kit and Lit are the standard capital and labour inputs respectively. The input $\mathrm{Pt}$ is an index of public knowledge and seen as a positive externality in equation (1)

The knowledge externality has two main properties:

Knowledge externality is primarily generated by the export sectors as a result of both learning-by-exporting and learning-by-doing. Learning-by-exporting arises when an export sector acquires knowledge from their foreign purchasers who share part of their know-how and offer advice on productivity enhancement. On the other hand, the basic idea behind learning-by-doing is that knowledge creation occurs as a by-product of production and it depends on the firm's cumulative output.

Hence, firms will increase their stock of knowledge as they expand their exports, and this accumulation process will accelerate as a firm exposes itself to competitive international markets.

Gustavo (2009) assumed that each export sector St produces an equal amount of public knowledge Pt. Hence, a nation's level of aggregated knowledge is given by the following equation

$\mathrm{Pt}=$ St Pet

Given that Pet is a constant and not directly observable parameter, the level of knowledge in the economy can be instead expressed as a function of the number of export sector

$\mathrm{Pt}=\mathrm{Z}(\mathrm{S}) \mathrm{t}$

It is assumed that primary goods tend to have a lower potential for learning-by-doing and learning-by-exporting comparatively to manufactured goods. Consequently, they hypothesized that the pace of knowledge creation in the economy will increase with an increase in the share of manufactured products in total exports.

Based upon this premise, a new knowledge equation can take the following form

$\mathrm{Pt}=\mathrm{Z}(\mathrm{St}, \mathrm{MXt})$

Where the share of manufactured products in total export (MXt) and the number of export sectors (St) are proxies for the stock of knowledge in the economy

The second main property of this model is that knowledge Pt is considered a public good and constant within all sectors. By treating Pt as a given, our production function fit has constant-returns-to-scale. It is also assumed that all firms operate in perfect competition and are price takes.

Now, the aggregate production $\mathrm{Yt}$ is written as function $\mathrm{n}$

$\mathrm{Yt}=\Sigma \mathrm{Yi}, \mathrm{t}=\mathrm{fi}, \mathrm{t}($ Kit, Lit, Pt)

$\mathrm{i}=1$

Inserting the public knowledge parameter of equations (4) into the production function, we get

$\mathrm{Yt}=\mathrm{fit}(\mathrm{kit}, \mathrm{Lit})(\mathrm{St}, \mathrm{MXt})=\mathrm{Kt} \beta \mathrm{Lt} \delta \mathrm{St} \psi \mathrm{MXt} \gamma$

Where Kt and Lt represent respectively the stock of accumulated capital and labour force of the economy, and parameters are constant.

Inclusion of the number of export sectors and the shares of manufactured exports as explanatory variables to equation (6), it is implied that both horizontal and vertical export diversification influence economic growth via externalities of learning-by-doing and learning-by-exporting. That is, are greater than zero.

In order to test the second hypothesis, we made us of dynamic panel growth model based on GMM estimator developed by Arellano and Bond (1991)

To investigate the relationship between export diversification and per capita income, we will therefore use the equation of the system GMM estimator similar to Laderman and Maloney (2007).

Therefore, we estimate a general growth equation of the form:

$\Delta \mathrm{yi}, \mathrm{t}=\alpha \mathrm{yi}, \mathrm{t}-1+\mathrm{X}^{\prime} \mathrm{i}, \mathrm{t} \beta+\mathrm{yt}+\eta \mathrm{i}+\mathrm{vi}, \mathrm{t}$

Where $\Delta y i, t$ denotes the log differences of income per capita in period t, yi,t-1 is the log initial income, Xi,t is a vector of potential determinants of growth, yt captures sample-wide time effects, $\eta \mathrm{i}$ are the unobserved timeinvariant country-specific effects, and $\mathrm{Vi}, \mathrm{t}$ is the residual error component.

\section{Methods}

To empirically justify the research objectives and obtain the long-run relationship between growth and export diversification, hereby validating the extent of growth induced by increasing manufacturing export value added and its returns to societal development; two models shall be developed to test each of the hypothesis. 


\subsection{ECOWAS Growth-Diversification Model}

To empirically test the long-run relationship between economic growth and increased manufacturing value added (diversification) in the ECOWAS region, the equation below is deemed fit

Yt $=$ ECIt $\varphi$, EDIt $\beta$

Where Yt is real GDP in period t, EDIt is the export diversification index of Ecowas region and ECIt Export concentration index.

Transforming equation (7) into a log-linear regular form, we have

$\log Y \mathrm{t}=\alpha+\varphi \log \mathrm{ECIt}+\beta \log \mathrm{EDI}+\mathrm{vt}$

Where $\log$ is the natural logarithm of the variable, and estimates $\varphi, \beta$ represent elastisities. The error term vt is assumed to be white-noise (random walk) normally and identically distributed.

Equation (9) will be subjected to empirical scrutiny and the model will test the diversification-led growth hypothesis for the manufacturing sector in Ecowas states.

Ho : $\varphi, \beta=0$

$\mathrm{H} 1: \varphi, \beta>0$

It is hypothesized that estimates $\varphi, \beta$ are positive and statistically significant, thus confirming the diversification-led growth.

\subsection{Panel Per capita trade growth model}

In the testing the country specific diversification induced growth in the Ecowas region, a model form of the GMM estimator will be adopted but the empirical validation shall be based on ordinary panel regression.

$\Delta y i, t=\alpha y i, t-1+X^{\prime} i, t \beta+v i, t$

Where $\Delta y i, t$ denotes log difference of income per capita in period t, yi,t-1 is the log initial income, Xi,t is a vector of potential determinants of growth and $\mathrm{Vi,t}$ is the residual error component.

$\mathrm{X}^{\prime} \mathrm{i}, \mathrm{t}=\mathrm{IVt} \alpha 1, \mathrm{AGRt} \alpha 2$, MFRt $\alpha 3, \mathrm{SEVt} \alpha 4$, SPEt $\alpha 5$

Where IVt is investment, AGRt is the share of agriculture contribution to GDP (agricultural value added), MFRt is the share of the manufacturing sector to GDP (Manufacturing value added), SEVt is the share of the service sector to GDP (services value added), and SPEt is the percentage share of primary export.

$\operatorname{logyi}, \mathrm{t}=\alpha 0+\alpha 1 \operatorname{logyi}, \mathrm{t}-1+\alpha 2 \log \mathrm{IVt}+\alpha 3 \log \mathrm{AGRt}+\alpha 4 \log \mathrm{MFRt}+\alpha 5 \operatorname{logSEVt}+\alpha 6 \log \mathrm{SPEt}+\mathrm{Vt}$

--- (12)

It is hypothesized that the estimates $\alpha 1, \alpha 2, \alpha 3, \alpha 4, \alpha 5, \alpha 6, \alpha 7$ are positive and statistically significant but a greater magnitude is expected from $\alpha 4, \alpha 5$ in order to appropriately validate the bases of the research.

Ho: $\alpha 1, \alpha 2, \alpha 3, \alpha 4, \alpha 5=0$

$\mathrm{H} 1: \alpha 1, \alpha 2, \alpha 3, \alpha 4, \alpha 5>0$

\subsection{Econometric Approach}

The study relies on secondary data; the 3 three member states of ECOWAS including Benin, Ghana, and Nigeria. The required data set on the variables to be tested in the models adapted for the study were drawn from these countries.

In performing the empirical analysis, the first step is to examine the time series properties of all the variables. For proper model specification, the unit root and co-integration test shall be conducted.

The Augmented Dickey-fuller (ADF) root tests for determining variables orders of integration shall be presented. The test for the order of stationary has led to the development of the Dickey- Fuller (1979) set of unit root tests. We test the null hypothesis of a difference stationary against the alternative hypothesis of a level stationary. That is:

$\mathrm{H} 0: \mathrm{Yt}=\mathrm{I}(1)$

$\mathrm{H} 1: \mathrm{Yt}=\mathrm{I}(0)$

With critical values which are all negative and larger (in absolute terms) than ADF statistics; if the null hypothesis cannot be rejected then Yt cannot be stationary. It may be I(1) or I(2) or have an even higher order of integration. The test for unit root is pertinent because it has been observed that, very often time series data are non-stationary. In such cases, the residuals of these time series are correlated with their own lagged values, thereby violating one of the standard Ordinary Least Square assumptions; hereby making estimates biased and inconsistent with standard errors generally underestimated. 
In determining the long-run relationship of the variables, the study shall adopt a co-integration test based on the approach of Johansen (1988) and Juselius (1990) for testing the long-run dynamic behaviour of variables under study. The vector error correction model shall be adopted for testing the short-run dynamics and guarantee successful correction of errors generated in each period within the model, the Johansen procedure unlike the Engel and Granger two steps static procedure allows the simultaneous evaluation of multiple relationships and imposes no prior restrictions on the co-integration space.

From the foregoing econometrical analyses, it is established that before regression analysis of equation model can be made, it is essential to identify the order of integration of each time series provided that the variable can be transformed into a stationary variable through differencing, concerning the dynamic growth model in equation above which is rewritten below.

$\operatorname{LOG}(\mathrm{Y})=\alpha 0+\varphi \mathrm{LOG}(\mathrm{ECI})+\beta \mathrm{LOG}(\mathrm{EDI})$

The differenced model can be written as

$\operatorname{LOG}(\mathrm{DY})=\alpha 0+\varphi \mathrm{LOG}(\mathrm{DEDI})+\beta \mathrm{LOG}(\mathrm{DECI})$

Most studies assume that time series data are stationary. However, it has been argued that this assumption is not appropriate for most economic variables and that these variables are better modeled as integrated of order one I(1) processes, that is, non-stationary and needs to be differenced once to become stationary.

A non-stationary series can be reviewed as a testable hypothesis by performing unit root test. A test for unit root has its origin in the work of Fuller (1976) and Dickey and Fuller $(1979,1981)$. The theory of co-integration arises out of the need to ensure the long run equilibrium or relationship of the observed variables. The theoretical stages involved are as follows.

\subsection{Testing for the order of the integration of the series}

The test for the order of stationary has led to the development of the Dickey- Fuller (1979) set of unit root tests. We test the null hypothesis of a difference stationary against the alternative hypothesis of a level stationary. That is:

$\mathrm{H} 0: \mathrm{Yt}=\mathrm{I}(1)$

$\mathrm{H} 1: \mathrm{Yt}=\mathrm{I}(0)$

With critical values which are all negative and larger (in absolute terms) than ADF statistics; if the null hypothesis cannot be rejected then Yt cannot be stationary. It may be I(1) or I(2) or have an even higher order of integration.

3.5 Co-integration Representation

After determining the order of integration as established in the first stage, the second stage proceeds to obtain the cointegrating vector in the regression equation. This is conducted using the Johansen procedure, the indication of one (unique) co-integrating vector at appropriate lag that ensure non serial correlation confirms the convergence of the estimated variables.

\subsection{Error Correction Modeling Representation}

Having established the long run series convergence, and that the variables are co-integrated, the third stage proceeds to estimate the error correction representation. The ECM incorporates the full (short run) dynamics of the model specified above. The theory of error correction model arises out of the need to integrate short run dynamics with long run equilibrium. At this stage all the conventional statistical tests of significance are considered to be appropriate including the diagnostic tests for the assessment of the adequacy of the model. Co-integration is a necessary condition for error correction model to hold.

The purpose of the ECM is to switch to a short run model. Allowance is made for any short run divergence, in a corrective mechanism by which previous disequilibria in the relationship between the level of money balance and the level of one or more of its determinants, are permitted to affect the current change in money holdings.

Theory expects that the ECM be negative and highly significant implying that an error in the current period is being corrected in the previous period.

In estimating the model two, a panel least square analytical procedure is attempted to sieve the effects of the trade composition indicators on per capita income. Afterwards, the model estimated the country and period fixed effects. 


\section{Results}

\subsection{Descriptive Statistic}

Descriptive statistics in this study considers important elements such as the mean, standard deviation, skewness and kurtosis for the variables used in the study where the interaction of data are described as given thus.

Table 1 Summary of Descriptive Statistics

\begin{tabular}{llllll}
\hline Variables & OBS & Mean & Std. Dev & Min & Max \\
\hline PEXP & 81 & 55.36 & 18.76 & 12.40 & 81.29 \\
\hline AGDP & 81 & 26.97 & 5.40 & 21.34 & 36.57 \\
\hline SGDP & 81 & 45.39 & 6.31 & 35.91 & 54.36 \\
\hline MSCT & 81 & 13.71 & 4.91 & 7.42 & 21.19 \\
\hline
\end{tabular}

Source: Researchers Computation, 2019

The above presented table 1 presents the summary of the descriptive statistics for the parameters used specifically agricultural produce as a percentage of GDP (AGDP) is the dependent variable, while primary exports, Service as a percentage of Gross Domestic Product (SGDP), and Main Sector Performance (MSCT) as the independent variables.

Primary export for the period of study and for the three countries namely Benin Republic, Nigeria, and Ghana has an average value of 55.36. The primary exports of these countries deviated by 18.76 while its minimum value stood at 12.40 and its maximum value stood at 81.29. Agricultural produce as a percentage of gross domestic product has an average percentage of $26.97 \%$, it was highest at $36.57 \%$, lowest at $21.35 \%$, and its standard deviation was $5.40 \%$. Service as a percentage of gross domestic product has an average value of $45.39 \%$, its standard deviation stood at $6.31 \%$, the maximum value is $54.36 \%$ and the minimum value is 35.91 . The main sector performance has an average value of 13.71, it deviated by 4.91, the minimum value stood at 7.42, and the maximum value is 21.19 .

\subsection{Correlation Matrix}

Table 2 shows the correlation values between the dependent and independent variable and covariance matrix (amongst themselves). Correlation matrix depicts the level of association between and among all pairs of variables given the level of significance.

Table 2 correlation matrix

\begin{tabular}{lllll}
\hline Variables & PEXP & AGDP & SGDP & MSCT \\
\hline PEXP & 1.0000 & & & \\
\hline AGDP & 0.2567 & 1.0000 & & \\
\hline SGDP & -0.1225 & 0.7024 & 1.0000 & 1.0000 \\
\hline MSCT & 0.1043 & -0.7450 & -0.9862 & \\
\hline
\end{tabular}

Source: Researchers Computation, 2019

From the presented result, primary exports have a positive but weak association with agricultural produce as a percentage of gross domestic products. This implies that as the level of agricultural produce increases, primary exports also increase. The correlation coefficient between primary exports and service as a percentage of gross domestic products is -0.1225 . This implies that there is a negative and weak correlation between primary exports and service as a percentage of GDP. Invariably, it can be said that the level of primary exports may not be related with the service sector, thus, the association is expected. The main sector performance is found to be positively correlated with the primary exports in the selected ECOWAS countries. It therefore means that primary export is expected to move in the same direction in which the main sector performance moves. Although the correlation is found to be weak but it is a positive correlation.

Agricultural produce as a percentage of GDP is found to be positively correlated with service sector as a percentage of GDP. This may be explained as seeing more expertise in the agricultural sector due to the involvement of technical know-how of those in the service sector. The correlation coefficient between agricultural gross domestic product and service as a percentage of GDP stood at 0.7024. A negative correlation and strong one is found to exist between agriculture as a percentage of GDP and the main sector performance. The correlation coefficient is found to be -0.7450 implying that as one variable increases, the other is on the decrease.

A negative and strong correlation coefficient is found between the service sector as a percentage of GDP and main sector performance in the selected ECOWAS countries. The correlation coefficient stood at -0.9862 implying that the main sector performance would reduce should the service sector performance as a percentage of GDP increases. 


\subsection{Pre-Test Statistics}

4.3.1 Panel Data Unit Root Test

Table 3 below shows the summary of the panel data unit root analysis using the Levin, Lin and Chu method at level and first difference. The result of this method is also backed up by the result of the Augmented Dickey Fuller (ADF) method as well as the Phillip Perron (PP) method.

Table 3 Summary of Panel Unit Root at Level

\begin{tabular}{lll}
\hline Var & t-test & p-val \\
\hline PEXP & 0.02341 & 0.5093 \\
\hline AGDP & -0.53009 & 0.2980 \\
\hline SGDP & -0.44049 & 0.3298 \\
\hline MSCT & -0.37367 & 0.3543 \\
\hline
\end{tabular}

Source: Researcher Computation (2019)

Table 4 Panel Unit Root at First Difference

\begin{tabular}{llll}
\hline Var & t-test & p-val & Remarks \\
\hline PEXP & -1.73730 & 0.0412 & $\mathrm{I}(1)$ \\
\hline AGDP & -5.77450 & 0.0000 & $\mathrm{I}(1)$ \\
\hline SGDP & -3.87605 & 0.0001 & $\mathrm{I}(1)$ \\
\hline MSCT & -5.88380 & 0.0000 & $\mathrm{I}(1)$ \\
\hline
\end{tabular}

Source: Researcher Computation (2019)

From the result of the panel data unit root reported in the above table, it was discovered that all the variables are stationary at first difference. As such, the stationary level of the variables is employed in the analysis of the study. The pooled ordinary least square, fixed effect and random effect will be examined at first difference in order to avoid or correct the likely problem of autocorrelation which may occur while using the variables even while they are not stationary.

4.3.2 Hausman Specification Test

Table 5 summarized the Hausman specification test for random effect.

\begin{tabular}{llll}
\hline Test Summary & $\begin{array}{l}\text { Chi-Sq. } \\
\text { Statistic }\end{array}$ & Chi-Sq. d.f. & Prob. \\
\hline Period random & 1.531497 & 3 & 0.6750 \\
\hline ** WARNING: estimated period random effects variance is zero. & \\
\hline
\end{tabular}

Period random effects test comparisons

\begin{tabular}{lllll}
\hline Variable & Fixed & Random & Var(Diff.) & Prob. \\
\hline D(MSCT) & -1.248366 & -1.207472 & 0.012895 & 0.7188 \\
\hline D(PEXP) & 0.054854 & 0.030956 & 0.000482 & 0.2762 \\
\hline D(SGDP) & -0.446702 & -0.432045 & 0.000760 & 0.5951 \\
\hline
\end{tabular}

Source: Researcher Computation (2019)

The Hausman specification test is conducted to select between the fixed effect and random effect. The null hypothesis is that random effect is appropriate while the alternative hypothesis states that fixed effect is appropriate. From the result of the Hausman test, the probability value is 0.6750 which signifies that the test is not significant at $5 \%$ level of significance. Therefore, the study makes use of the random effect because the test tells that the random effect is appropriate since the test is not significant at $5 \%$.

The pooled regression result is summarized in Table 6 below. This result will assist in empirically verifying the first hypothesis of the study. The first hypothesis states that exports and imports have no significant impact on trade performance in ECOWAS countries.

Table 6 Summary of Pooled OLS Result

\begin{tabular}{lllll}
\hline Variable & Coefficient & Std. Error & t-Statistic & Prob. \\
\hline $\mathrm{C}$ & -0.207084 & 0.248105 & -0.834665 & 0.4068 \\
\hline $\mathrm{D}(\mathrm{MSCT})$ & -1.244974 & 0.192367 & -6.471874 & 0.0000 \\
\hline $\mathrm{D}$ (PEXP) & 0.054640 & 0.034682 & 1.575438 & 0.1197 \\
\hline
\end{tabular}




\begin{tabular}{lclll}
\hline $\mathrm{D}(\mathrm{SGDP})$ & -0.443001 & 0.055950 & -7.917787 & 0.0000 \\
\hline \multicolumn{4}{l}{ Effects Specification } \\
\hline \multicolumn{4}{l}{ Cross-section fixed (dummy variables) } \\
\hline \multicolumn{2}{l}{ Period fixed (dummy variables) } \\
\hline R-squared & 0.693244 & Mean dependent var & - \\
\multicolumn{4}{l}{} & \\
\hline Adjusted R-squared & 0.510969 & S.D. dependent var & 3.786876 \\
\hline S.E. of regression & 2.595643 & Akaike info criterion & 5.026878 \\
\hline Sum squared resid & 464.8779 & Schwarz criterion & 6.052106 \\
\hline Log likelihood & -236.9918 & Hannan-Quinn criter. & 5.442783 \\
\hline F-statistic & 3.803285 & Durbin-Watson stat & 1.931303 \\
\hline Prob(F-statistic) & 0.000001 & & \\
\hline
\end{tabular}

Source: Researcher Computation (2019)

The result of the pooled ordinary least square above depicts that main sector and service sector performance as a percentage of GDP are found to be significant factors that influence the level of trade performance in the ECOWAS countries.

Main sector performance is found to exert a negative relationship with trade performance in the selected ECOWAS countries with a coefficient of -1.24 , implying that as main sector performance increases by one percent, trade performance reduces by 1.24 percent. Also, service sector performance as a percentage of GDP is found to be negatively related with trade performance in the selected ECOWAS countries. This implies that a percentage increase in the performance of the service sector will lead to a 0.44 percent decrease in trade performance in the ECOWAS countries.

The study therefore rejects the first hypothesis that states that there are no significant determinants of trade performance in the ECOWAS countries as the main sector performance as well as the service sector performance are found to be significant factor that influences trade performance in the selected ECOWAS countries.

Furthermore, in achieving the second and third objectives of the study, the fixed effect result of the ordinary least square is presented below.

Table 7 Summary of the Random Effect OLS

\begin{tabular}{|c|c|c|c|c|}
\hline Variable & Coefficient & Std. Error & $\mathrm{t}$-Statistic & Prob. \\
\hline $\mathrm{C}$ & -0.219775 & 0.245051 & -0.896854 & 0.3718 \\
\hline$\overline{\mathrm{D}(\mathrm{MSCT})}$ & -1.207472 & 0.152748 & -7.905006 & 0.0000 \\
\hline D(AGDP) & 0.030956 & 0.026356 & 1.174554 & 0.2428 \\
\hline \multirow[t]{3}{*}{$\mathrm{D}$ (SGDP) } & -0.432045 & 0.047518 & -9.092210 & 0.0000 \\
\hline & \multicolumn{4}{|c|}{ Effects Specification } \\
\hline & & & S.D. & Rho \\
\hline Period random & & & 0.000000 & 0.0000 \\
\hline \multirow[t]{2}{*}{ Idiosyncratic random } & & & 2.568947 & 1.0000 \\
\hline & \multicolumn{4}{|c|}{ Weighted Statistics } \\
\hline R-squared & 0.542008 & \multicolumn{2}{|c|}{ Mean dependent var } & $\begin{array}{l}- \\
0.486876\end{array}$ \\
\hline Adjusted R-squared & 0.529167 & \multicolumn{2}{|c|}{ S.D. dependent var } & 3.711734 \\
\hline S.E. of regression & 2.546890 & \multicolumn{2}{|c|}{ Sum squared resid } & 694.0716 \\
\hline F-statistic & 42.20950 & \multicolumn{2}{|c|}{ Durbin-Watson stat } & 1.952857 \\
\hline Prob(F-statistic) & 0.000000 & & & \\
\hline
\end{tabular}

Source: Researcher Computation (2019)

The second hypothesis of the study states that there is no significant impact of the determinants of trade performance on exports performance in the selected ECOWAS countries. The result presented in Table 7 above indicates that main sector performance and service sector performance influence export performance in the selected ECOWAS countries. 
Main sector is found to influence exports performance in these selected countries negatively such that a percentage change in the performance of the main sector will lead to a decrease in export performance by 1.20 percent. The study found an indirect and significant relationship between main sector performance and export performance in the selected ECOWAS countries. It was also discovered in the result of the random effect OLS above that primary export does not significantly influence the performance of exports in the selected ECOWAS countries. This however does not follow theoretical backings. There is a positive relationship but the relationship is found to be insignificant and as such, the effect of primary exports on export performance can be disregarded.

Furthermore, it was discovered in the study that service sector performance as a percentage of GDP influences a negative effect on exports performance in the selected ECOWAS countries such that a percentage increase in the service sector performance as a percentage of GDP will lead to a 0.43 percentage decrease in export performance.

\subsection{Coefficient of Determination (R2)}

The coefficient of determination is used to measure the strength of the relationship between the dependent variable and the independent variables. It measures the extent to which variations in the independent variables explain the variations in the dependent variable. From the result of the test above, the coefficient of determination is found to be 0.542008 implying that 54.20 percent of the variations in the export performance is explained by variations in main sector performance, primary exports, and service sector as a percentage of GDP while the remaining 44.80 percentage are explained by factors which are not included in the model.

\subsection{F-Statistics}

The F-statistics is used to measure the joint significance of the independent variables on the dependent variable. The F-statistics value of the study stood at 42.20950 with probability of 0.0000 implying that the independent variables significantly influence the performance of exports in the selected ECOWAS countries. It therefore implies that main sector as a percentage of GDP, primary exports and service sector as a percentage of GDP jointly have significant influence on export performance in the selected ECOWAS countries.

4.6 Residual Test

4.6.1 Durbin Watson Test

The Durbin Watson test is used to understand if there is the problem of autocorrelation in the residuals of the variables employed in the study. The DW value of the result is 1.952857 . Using the rule of thumb, the study can be said to be free from the problem of autocorrelation since the DW value is very close to 2 . Another proof is that the DW value is greater than the $\mathrm{R}^{2}$ value, therefore it can be said that the model is free from the problem of autocorrelation.

4.6.2 Normality Test and Stability of the Model

\section{Figure 1}

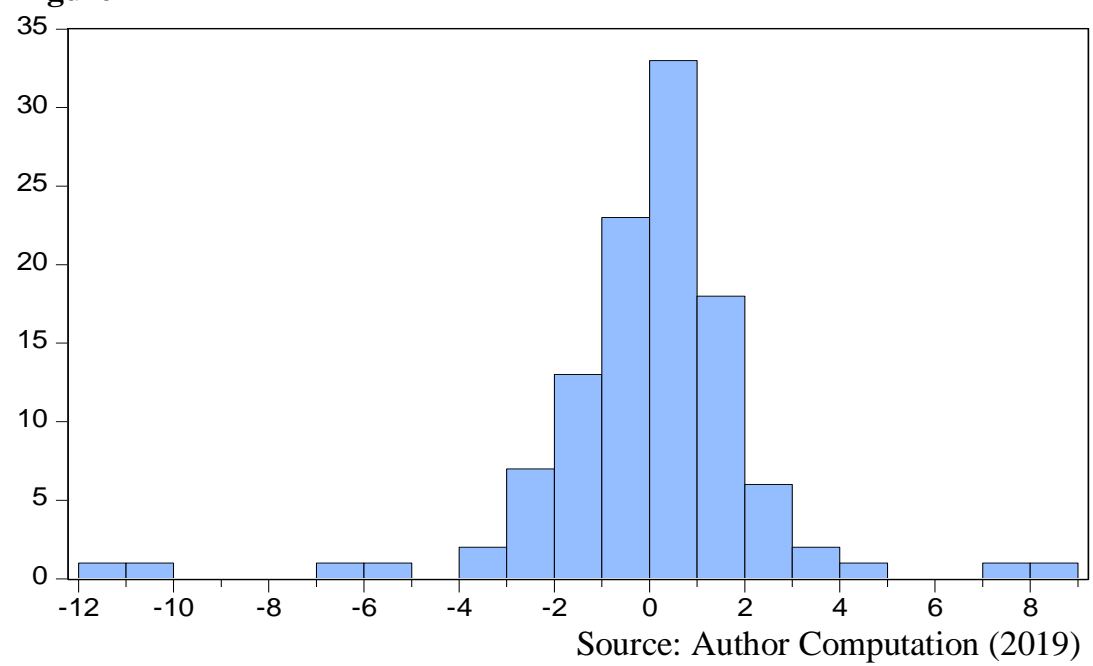

Series: Standardized Residuals

Sample 19812017

Observations 111

$\begin{array}{lr}\text { Mean } & 0.000000 \\ \text { Median } & 0.210791 \\ \text { Maximum } & 8.692923 \\ \text { Minimum } & -11.39175 \\ \text { Std. Dev. } & 2.511920 \\ \text { Skewness } & -1.154540 \\ \text { Kurtosis } & 10.48012 \\ & \\ \text { Jarque-Bera } & 283.4388 \\ \text { Probability } & 0.000000\end{array}$

The Jarque-Bera test is used to check for the normality of the variables and also the stability of the model. The Jarque-Bera value is 283.4388 with the probability value of 0.0000 . The null hypothesis is that the variables are not normally distributed. The null hypothesis is therefore rejected since the test is significant at $5 \%$ level of significance and thus it can be concluded that the model is normally distributed. 


\section{Discussion and Implications of Findings}

The study has looked at the determinants of exports and imports in some selected ECOWAS countries. The selected ECOWAS countries are Benin, Ghana, and Nigeria. The study revealed that the activities of the main sector when rated as a percentage of the gross domestic product is a significant factor that influences the exports and imports in these selected countries. This means that the activities done in the main sector of these economies have significant effect on the value of exports and imports. The activity of the main sector is huge and voluminous enough to accommodate some level of significant imports in order to assist production which will also be exported. The study has also revealed that the service sector is also a significant factor that influences the exports and imports of these selected ECOWAS countries. Many experts are imported into the service sector of these countries and thus these served as a significant factor that possess influence on the performance of exports and imports in the countries.

The study also revealed that the primary export is not significant enough to influence the level of imports and exports in the selected ECOWAS countries. This finding is against the findings of Aissata, Siba and Hady (2018); Santos-Paulino (2000) which found that potential trade was significant in the European Union and that exports react negatively to an increase in relative prices.

\section{Conclusion}

In this study, an attempt was made to determine the effect of trade diversification on economic growth of ECOWAS countries. West African countries are growing at a satisfactory rate, but it does not change the fact that many are not only on a Less Developed Countries status, still fail to diversify to promote a more inclusive growth. Africa is still lagging when it comes to regional, trade integration and seems to rely more on the rest of the world than their closest neighbors. Policies with new approaches and techniques tailored to the African market must be enacted and implemented to drift away from superficial cooperation agreements of simple deregulation and trade liberalization and dive into deeper levels of integration. In order to do so, regional and trade integration should be a priority.

Main sector performance is found to exert a negative relationship with trade performance in the selected ECOWAS countries with a coefficient of -1.24 , implying that as main sector performance increases by one percent, trade performance reduces by 1.24 percent. Also, service sector performance as a percentage of GDP is found to be negatively related with trade performance in the selected ECOWAS countries. This implies that a percentage increase in the performance of the service sector will lead to a 0.44 percent decrease in trade performance in the ECOWAS countries.

The study therefore rejects the first hypothesis that states that there are no significant determinants of trade performance in the ECOWAS countries as the main sector performance as well as the service sector performance are found to be significant factor that influences trade performance in the selected ECOWAS countries. Based on the findings in this study, the following recommendations are suggested; (1) There is urgent need for ECOWAS states to place more emphasis on the exports of manufacturers' products and make efforts to reduce concentration on exports of primary (agriculture and fuel) products. This will help improve their international trade performance especially with respect to reducing term of trade losses and unfavourable shocks in foreign earnings. (2) Also, the region should focus on production of products for domestic need; in doing this, the ECOWAS states will escape the trap of homogenous export and foster more intra-trade links. The region should see production as major objective rather than exports; this enhances industrial activities and innovations in the region. This attempt retains economic gains of resource within the region and foster economic well-being, the critical mass of ECOWAS challenge is weak productive capacity, this has accentuated the progress of the member states and the sole cause of social and economic evils within the region. ECOWAS should see exports as originating from domestic sufficiency. (3) ECOWAS needs to concentrate efforts on exports of commodities that attract more stable earnings by increasing the value-added of its major exports and encouraging investment into viable sectors. Continue dependence on primary commodities would only diverge the region from achieving stationary stage of income and perpetually place the region in income trap; concentration of efforts on quick supply response and highly dynamic products which attract higher price in the international market would revive the economies of the region. (4) Also, the region should attempt a horizontal diversification in the short-run by expanding the variety of usefulness of its export basket. For instance, products such as Cocoa, Crude, Coffee etc can be processed into their various useful-ness before exporting rather than exporting in crude form. Industries should be developed to explore and handle several components of these products. Crude for instance, at processing stage can be sieved into several components such as gases, kerosene, diesel, motor oil, petroleum jelly, etc; this implies that several industries can be developed from crude resource. (5) The ECOWAS member states should concentrate on mass injection of capital investment in viable 
sectors of their economies, the region should invest heavily in developing sectors that are capable of generating spill-over and export discovery that would enhance comparative advantage along a new export cluster and facilitate the emergence of new exports. This would accentuate the level of human capital utilization, societal advancement and global trade penetration of the region.

\section{References}

Aron, J., Elbadawi, I. and Khan, B. (1997). Determinants of real exchange rate in South Africa. Working Paper for Centre for Studies of African Economics and Statistics, Oxford University, 16, 45-62.

Aliyu, S. R.(2011). Impact of oil price shock and exchange rate volatility on economic growth in Nigeria: An empirical investigation. Research journal of international studies,4(11),220-231.

Aliyu, S., Yakub, M., Sanni, G., and Duke, O. (2013). Exchange Rate Pass-through in Nigeria : Evidence from a Vector Error Correction Model. EconPaper, 1071-1084.

Bundesbank, D. (2010). Nominal and real exchange rate movements during the financial crisis. Deutsche Bundesbank Monthly Report, (July), 39-55.

Bahmani-Oskooee, M. (1991). Is there a long-run relation between the trade balance and the real effective exchange rate of LDCs? Economics Letters, 36, 403-407.

Bahmani-OskooeeM, Economidou C, and Goswami G, G., (2005). Export-led growth hypothesis revisited: a panel cointegration approach. Scientific Journal of Administrative Development 3:40-55.

Choudhri, E. and Schembri, L. (2014). Productivity, commodity prices and the real exchange rate: The long-run behavior of the Canada-US exchange rate. International Review of Economics \& Finance, 29, 537-551.

Gbesola, A. and Garba, T. (2014). Trend of the Nigeria exchange rate from 1970-2013 (pp.32-43).

Idika, K.U. (1998). Nigeria foreign exchange markets. Management and Development. Spectrum Book Ltd. Ibadan. Nigeria International Monetary Fund (1984). Exchange rate variability and world trade, IMF Occasional Paper 28

Martin, W., 2001. “Trade policies, developing countries and globalization”. Development Research Group. Washington DC: World Bank.

Mordi, C. N. (2006). Challenges of exchange rate volatility in economics management in Nigeria. Central Bank of Nigeria Bullion. 30(3)

Mahmood, I. \& Ali, S. Z. (2011). Impact of Exchange Rate Volatility on Macroeconomic performance of Pakistan, International Research Journal of Finance and Economics, issue 64. pp. 1450-2887.

Medina-Smith, E. J. 2001. "Is the Export Led Growth Hy-pothesis Valid for the Developing Countries? A Case Study for Costa Rica," Policy Issues in International Trade and Commodities, Study Series Number 7 , United Nations Con-ference on Trade and Development.

Tarawalie, A. B., Sissoho, M., Conte, M., and Ahortor, C. R. (2012). Exchange Rate, Inflation and Macroeconomic Performance in the West African Monetary Zone (WAMZ). WAMI Occasional Paper Series No. 2

\section{Copyrights}

Copyright for this article is retained by the author(s), with first publication rights granted to the journal. This is an open-access article distributed under the terms and conditions of the Creative Commons Attribution license (http://creativecommons.org/licenses/by/4.0/). 